\title{
FINANCIAL CONSTRAINTS AND STOCK RETURNS
}

\author{
Owen Lamont \\ Christopher Polk \\ Jesús Saá-Requejo
}

Working Paper 6210 
NBER WORKING PAPER SERIES

\title{
FINANCIAL CONSTRAINTS AND STOCK RETURNS
}

\author{
Owen Lamont \\ Christopher Polk \\ Jesús Saá-Requejo
}

\author{
Working Paper 6210 \\ http://www.nber.org/papers/w6210

\section{NATIONAL BUREAU OF ECONOMIC RESEARCH 1050 Massachusetts Avenue \\ Cambridge, MA 02138} \\ October 1997
}

We thank Jason Abrevaya, Judith Chevalier, Kent Daniel, Eugene Fama, Anil Kashyap, Jay Ritter, Sheridan Titman, Robert Vishny, and participants at the University of Chicago finance seminar for helpful comments. We thank Alon Brav, Mark Carhart, Eugene Fama, Steven Kaplan, Ilian Mihov, Brian P. Sack, James Stock, and Luigi Zingales for providing data. Lamont was supported by the Center for Research in Securities Prices and the FMC Faculty Research Fund at the Graduate School of Business, University of Chicago. Saá-Requejo was supported by a DF $\Lambda$ research grant. This paper is part of NBER's research programs in Asset Pricing and Monetary Economics. Any opinions expressed are those of the authors and not those of Goldman Sachs International or the National Bureau of Economic Research.

(C) 1997 by Owen Lamont, Christopher Polk and Jesús Saá-Requejo. All rights reserved. Short sections of text, not to exceed two paragraphs, may be quoted without explicit permission provided full credit, including (C) notice, is given to the source. 
Financial Constraints and Stock Returns

Owen Lamont, Christopher Polk

and Jesús Saá-Requejo

NBER Working Paper No. 6210

October 1997

JEL Nos. G12, G32, E44

Asset Pricing and Monetary Economics

ABSTRACT

We test whether the impact of financial constraints on firm value is observable in asset returns. We form portfolios of firms based on observable characteristics related to financial constraints, and test for common covariation in the stock returns of these firms. Using several different measures of financial constraints, we find that financially constrained firms' stock returns move together over time. This financial constraint factor in stock returns is related to, but not well explained by, other empirically identified factors in asset returns. Constrained firms have remarkably low returns in our sample period of 1968-1995, both unconditionally and in the context of empirical asset pricing models. Financial constraint returns help explain returns following initial public offerings and dividend omissions. We find only limited support for the hypothesis that the relative performance of financially constrained firms reflects monetary policy, credit conditions, and business cycles.

Owen Lamont

Graduate School of Business

University of Chicago

1101 East 58th Street

Chicago, IL 60637

and NBER

owen.lamont@gsb.uchicago.edu
Christopher Polk

Graduate School of Business

University of Chicago

1101 East 58th Street

Chicago, IL 60637
Jesús Saá-Requejo

Graduate School of Business

University of Chicago

1101 East 58th Street

Chicago, IL 60637 
Financial Constraints and Stock Returns

Do firms face financial constraints that hamper their ability to invest? To examine this question, researchers typically examine quantity data such as credit flows or real activity, both for individual firms and macroeconomic aggregates. We instead examine this question using asset price data and sorted portfolios of traded securities. We test whether firms which appear to be financially constrained share common covariation in their stock returns. We construct a portfolio of financially constrained firms, and then use the time series of portfolio returns to examine the relationship of financial constraints to the business cycle and monetary policy. By "financially constrained," we mean that, broadly, the firm is not able to fund all the projects it wants to. This might be due to credit constraints or inability to borrow, inability to issue equity, dependency on bank loans, illiquidity of assets, or similar phenomena. We do not mean financial distress, economic distress, or bankruptcy risk, although these things may be correlated with financial constraint.

Our goal is to test whether there is a common source of covariation in the returns of firms with similar levels of financial constraints. If financial constraints are an important determinant of the value of a corporation, changes in their intensity should be reflected in stock returns. If changes in financial constraints are solely a firm-specific, idiosyncratic phenomenon, then constrained firms' returns have no reason to move together, controlling for other sources of common covariation among asset returns (such as the overall market). However, if constrained firms are subject to common systematic shocks, there will be common covariation in the returns of firms with similar levels of financial constraint. For example, if an unexpected "credit crunch" makes it more difficult for some firms to undertake profitable 
projects, then these firms will have their expected future cash flows, and thus their stock prices, fall together.

In the terminology of asset pricing, we test whether there is factor in stock returns that reflects financial constraints. A factor is simply an explanatory variable that helps describe stock returns. In a multifactor model, where $r$ is the return on any asset or portfolio of assets, a factor is an $f_{j}$ such that $r=a+\sum_{j=1}^{K} \beta_{j} f_{j}+\epsilon$

As is standard, we construct the $f_{j}$ 's using returns on portfolios that are long on one set of assets, and short on another set.

Stock returns contain economic information because observed returns are composed of three parts: expected stock returns, changes in expected future returns, and changes in expected future cash flows. Since revisions in future expected cash flows and returns contain common components across firms, economic structure causes factor structure in stock returns. For example, the stock returns of oil firms move together because revisions in their future expected cash flows move together. If we wanted to test the economic hypothesis of whether oil firms' future cash flows depend on petroleum prices, we could run a regression of an "oil factor" (constructed from oil firms' stock returns) on petroleum prices. The hypothesis we wish to test here is that there are common components in stock prices due to financial constraints.

In the context of existing empirical asset pricing models, we will test whether financial 
constraints are an independent source of movement in returns. It could be, for example, that constrained firms have high market $\beta$ 's but nothing else; in this case, financial constraints might be an important determinant of firm value but they would not be independently identifiable through stock returns.

If we find no financial constraint factor, that would suggest that financial constraints are not an important determinant in the cross-section of returns, and that financial constraints do not expose firms to common shocks. If we do find a financial constraint factor, we can use the estimated time-series of its factor-mimicking returns to address unresolved economic questions. We study questions in two areas: finance and macroeconomics.

First, in the area of asset pricing, we relate the financial constraint factor to other empirically identified factors in asset returns. Is the constraint factor subsumed by other factors in asset returns, such as the market factor, the book-to-market factor, and the size factor? Is it a priced factor - does it earn a risk premium to compensate for the risk it bears? Much of asset pricing research focuses on the cross-section of expected returns, and whether they can plausibly be explained by rational risk-based factor models. In contrast, our goal is not to (necessarily) find a priced factor, but rather to find a factor that measures an economically meaningful variable. So unlike Fama and French (1992), for example, we design our factor mimicking portfolio not to match known anomalies in existing asset pricing models, but to measure an economically meaningful concept.

In finding a financial constraint factor and relating it to existing factors, our results shed some light on the interpretation of existing empirical factor models. As it turns out, although we did not design our financial constraints factor in order to have a large non-zero 
mean, it does.

Second, in the area of macroeconomics and corporate finance, we ask whether the financial constraint factor moves systematically over the business cycle. Is it driven by macroeconomic fluctuations, credit conditions, or monetary policy?

A variety of macroeconomic models suggest that financial constraints are important in determining equilibrium real activity and asset prices (see Bernanke, Gertler, and Gilchrist (1996) for a review). These different models have common predictions, and we do not attempt to discriminate between their slightly different variations in our empirical tests. According to these theories, imperfect capital markets serve to magnify and propagate macroeconomic shocks. Testing of these theories is usually cross-sectional, and is valid under the assumption that some firms are more constrained than others, an assumption we also use here.

This paper is organized as follows. In section I, we review work in asset pricing, corporate finance, and macroeconomics that is relevant to our measure. In section II, we present the results from our measurement exercise, showing summary statistics and the path of the financial constraint factor over time. In section III, we relate our measure of the constraint factor to other asset returns. In section IV, we examine macroeconomic issues using the financial constraint factor. In section $\mathrm{V}$ we summarize and present conclusions.

\section{Relation to Previous Research}

\section{A. Multifactor Models in Asset Pricing}

Fama and French $(1992,1993)$ examine the cross-section of expected returns and find that stock returns can be described by a three factor model, with the three factors 
corresponding to the market return, the return on a portfolio reflecting high book-to-market stocks, and the return on a portfolio reflecting small stocks. Fama and French (1992) use their factors to explain Bhandari's (1978) result that firms with higher leverage earn higher average stock returns. Chan and Chen (1991) attempt to explain the size effect, and find that sensitivity to mimicking portfolios for measures of "marginal" financial status (cutting dividends and having high leverage) account for the size effect in the cross-section of expected returns. Shumway (1996) finds similar results.

In contrast to these papers, our goal is not to explain the size or book-to-market effect. We want to examine financial constraints. In doing so, however, we take into account existing empirical facts about firm characteristics and returns, and the well-known connection between size and the financial characteristics of firms.

\section{B. Macro and Corporate Finance}

In recent years, empirical work in macroeconomics and asset pricing has proceeded along parallel lines. For example, interest rate spreads forecast both output and asset returns (Stock and Watson (1989), Keim and Stambaugh (1986)) and may measure the stance of monetary policy and credit conditions (Kashyap, Stein, and Wilcox (1993)).

We use asset price data to test whether there is a common factor in stock returns related to financial constraints, and whether this common factor is related to monetary policy, credit conditions, or the business cycle. There is already suggestive evidence from small firms. Fama and French (1993) find that small firms have common covariation in their returns. Gertler and Gilchrist (1994) find that small firms have sales and inventories that are more cyclical and more responsive to downturns in monetary policy, controlling for industry. 
Thorbecke (1997) finds that small firm returns have higher loadings on monetary policy.

We are not interested in size for its own sake, but rather in financial constraints. Size is correlated with constraints, but is not a pure measure of constraints. Gertler and Gilchrist (1994) use size as a proxy for financial constraints because of data limitations. Fazzari, Hubbard, and Petersen (1988) find that size is not a good proxy for financial constraints compared to their preferred measure (dividend payout); others find similar results. ${ }^{1}$

A standard finding in the credit channel literature is that credit constraints are time-varying. Gertler and Hubbard (1988), Kashyap, Lamont, and Stein (1994) and Gertler and Gilchrist (1994) all show that credit constraints seem to bind more during recessions or when monetary policy is tight. These findings imply common covariation in the stock returns of financially constrained firms, as macroeconomic shocks (including monetary policy shocks and changes in credit conditions) differentially affect these firms.

\section{Data Construction and Summary Statistics}

\section{A. Data Construction}

To measure the financial constraint factor, we utilize firm-level information. We use firm characteristics to identify individual firms which are financially constrained, and use these firms to create factor-mimicking portfolios. We form these portfolios every year, and examine monthly returns from July 1968 to December 1995.

We construct four different measures of financial constraints. Our goal is to find characteristics of firms that are likely to be correlated with the ability of firms to finance

\footnotetext{
${ }^{1}$ Fazzari, Hubbard, and Petersen (1988) pages 160 and 168. Kashyap, Lamont, and Stein (1994) reach similar conclusions on size relative to bond ratings. Gertler and Hubbard (1988) find that size is inversely correlated with sales variability, but that after controlling for dividend payout rates this size effect disappears.
} 
investment, using characteristics from previous studies of corporate investment and financial constraints. In order to more easily test for common covariation across portfolios, we restrict ourselves to measures of financial constraints which take on continuous values and can be constructed using COMPUSTAT data.

We arrange all four measures so that increasing values signify higher financial constraints, and rank all firms in a given year on these values. Each June of year $t$, we form portfolios based on these rankings, using accounting data from the firm's fiscal year end in calendar year $t-1$. The factor mimicking portfolio return is the difference between the valueweighted return of the top $20 \%$ of firms ranked by the constraint measure, and the valueweighted return of the bottom $20 \%$ of firms ranked by the constraint measure. The factor mimicking returns are the returns one would get by buying highly constrained firms and shorting less constrained firms.

First, we define net cash flow (NCF) as after tax cash flow minus capital expenditures in the year, divided by net capital stock at the end of the previous year (precise data definitions are given in the appendix). We interpret firms that have high net cash flow as being less constrained.

Second, we construct a general index of financial constraints, $\mathrm{KZ}$, using results from Kaplan and Zingales (1997). Using the Fazzari, Hubbard, and Petersen (1986) sample of low dividends firms, Kaplan and Zingales judgmentally classify firms into discrete categories of financial constraint, and then use an ordered logit regression to relate their classifications to quantitative measures of accounting variables. We use their regression coefficients to construct an index consisting of a linear combination of five accounting ratios: cash flow to 
total capital, the market to book ratio (Tobin's q), debt to total capital, dividends to total capital, and cash holdings to capital. The $\mathrm{KZ}$ index is higher for more highly constrained firms. ${ }^{2}$

These first two measures are straightforward to construct. The next two measures are somewhat more complex, since they involve ratios with earnings (a variable which may be either positive or negative) as the numerator. Again, the goal is to produce a ranking of all firms in a given year.

Our third measure of financial constraints is interest coverage, IC. The traditional interest coverage ratio is earnings divided by interest expense. Since for some firms interest expense is zero, we do not rank firms on the traditional measure. Instead, we partition all firms into three groups, and rank firms according to the principle that higher interest expense means more constraints and higher earnings less constraints. The most constrained group consists of firms with nonpositive earnings; these we rank on the ratio of interest expense minus earnings, divided by capital stock. The middle group consists of firms with both positive earnings and positive interest expense; these we rank on the traditional coverage ratio. The least constrained group consists of firms with positive earnings but nonpositive interest expense; these we again rank in order of the ratio of interest expense minus earnings, divided by capital stock. The end result is a full ranking of all firms, intended to capture the magnitude of interest expense relative to earnings.

\footnotetext{
${ }^{2}$ Each variable has the expected sign, with the possible exception of the sign on Tobin's q, which has a positive coefficient in the regression but which univariately is negatively correlated with financial constraints, as discussed by Kaplan and Zingales (1997). We also note that Kaplan and Zingales estimated their index only for manufacturing firms paying low dividends, so we are applying their empirical results in a way not intended by Kaplan and Zingales.
} 
Last, we rank firms on dividend payout ratio, D/E. Fazzari, Hubbard, and Petersen (1986) reason that high-dividend paying firms must be relatively less constrained, and use long-term dividend payout ratios. Unlike them, we do not condition on multi-year levels but simply use a single year's dividend payout ratio. Since earnings and dividends are often nonpositive for some firm-years, we again partition the sample into three groups in order to produce rankings. We rank firms according to the principle that high dividends indicate low constraints, and high earnings indicate less constraint. In the most constrained group are firms paying zero dividends, which we rank by the ratio of net income to capital. In the middle group were firms with positive dividends but nonpositive net income; these we rank by net income to capital. Last were firms with positive dividends and positive net income; these we rank by the traditional dividend payout ratio.

To produce a single financial constraint factor mimicking portfolio, FC, we combine the information in the four measures at the ranking stage. We form combined rankings by ranking every firm each year by the four different measures, then averaging their percentile rankings. This combined ranking measures at the firm level the characteristic of being financial constrained. We sort firms on this constraint characteristic to construct what we call the constraint factor in returns. The constraint factor is a monthly time-series of returns on a zero-cost factor-mimicking portfolio for financial constraints.

\section{B. Summary Statistics and Firm Characteristics}

Table I shows the characteristics of decile portfolios, sorted on the combined FC rankings, and averaged over 1968-1995. As can be seen, high FC firms (those in deciles 9 and 10) are far smaller than other firms, and are disproportionately NASDAQ heavy. High 
FC firms have slightly lower than average book to market, high market $\beta$ 's, high leverage, and negative earnings. They are more likely to leave the sample in year following portfolio formation. In contrast, low FC firms have dramatically lower than average book to market and leverage.

The first column of Table I, which shows average monthly return by FC decile, reveals one of the most puzzling findings of this paper. The highest FC decile earns monthly nominal returns of only 32 basis points per month, which is less than the return on treasury bills of 56 basis points per month during this period. It is remarkable to find a portfolio of small, high $\beta$ firms that earn negative excess returns. We examine this puzzle further in sections II.D and III.

Table IIA shows summary statistics for the four financial constraint return series, and for the combined constraint measure (constructed by subtracting the value-weighted returns on the two highest deciles minus the two lowest deciles in Table I). Table IIA shows that the financial constraint factor, labeled FC in the tables, is (as intended) highly correlated with the four individual return series.

For comparison, we also show statistics for three other stock market factors used by Fama and French (1993): RM-RF, HML, and SMB. RM-RF, the market factor, is the return on a value-weighted portfolio of NYSE/AMEX/NASDAQ stocks minus the return on a portfolio of Treasury bills. HML (high minus low) is the book-to-market factor, constructed by subtracting a low book-to-market portfolio return from a high book-to-market portfolio return. SMB (small minus big) is the size factor, constructed by subtracting a large firm portfolio return from a small firm portfolio return (size is measured by market capitalization). 
For the rest of this paper, we use their factors to examine book-to-market and size.

The first question to ask is whether the financial constraint mimicking portfolio returns are just random noise. One measure of whether a mimicking portfolio is capturing common covariation is the standard deviation. If the long and short portfolios were just random, we'd expect the standard deviation to be small since the portfolios are well diversified. The standard deviations are substantial, on the same order of magnitude as the size, book-tomarket, and market factors.

The second question to ask is whether they all measure the same thing. All four have roughly similar means and variations, and are positively correlated over time. Figure 1 shows the time series of the cumulative returns on these portfolios from 1968 to 1995 . The return on the factor-mimicking portfolio represents the return one would get from a self-financing strategy of buying a portfolio of highly constrained firms and shorting a portfolio of less constrained firms. The cumulative returns are simply the sum of these monthly returns and show (an approximation of) the percent total return on the long portfolio minus the total return on the short portfolio.

Each one of our four measures has obvious problems in claiming to be an accurate measure of financial constraints. However, the strong similarities in the return series gives us confidence that all four return series are measuring the same thing.

The common characteristics shown in Table I suggest one possible explanation for the similar time-series patterns of our four measures: similar factor loadings on other factors, such as market, book-to-market, and size factors. Table IIA shows that all four of our series are highly correlated with the size factor. We next turn to changing the composition of the 
constraint factor, one way to examine this issue.

\section{FC Portfolio Composition and Matched Portfolios}

We now construct factor-mimicking portfolios that are matched for size, book-tomarket, trading exchange, and industry, and we show the importance of various different portfolio formation rules in the constructing constraint returns. Although the matched factormimicking portfolio returns provide valuable information, it turns out that the valuable information is chiefly about what is not driving our results.

There are two reasons to attempt to control for size, book-to-market, trading exchange, and industry. First, we want to make sure that our financial constraint factor is not just reflecting a common characteristic other than financial constraint. For example, we want to make sure that our financial constraint factor doesn't just reflect firms with high Tobin's $q$ (market-to-book) which might be expected to have special cyclical characteristics. Controlling for size and book-to-market has the interpretation of roughly replicating typical corporate finance methodology. In regressions of the type first run by Fazzari, Hubbard, and Petersen (1986), researchers typically ask: controlling for Tobin's q, do constrained firms have higher cash flow sensitivity than non-constrained firms? Similarly, by using matched portfolios, we ask: controlling for Tobin's $q$, do constrained firms have common covariation in their stock returns?

Analogously, by matching for size, we are able to control for the correlation of size and financial constraints. We want to make sure we are picking up differences in financial constraints, not differences in size due to the correlation of size and constraints.

We control for trading exchange (NASDAQ vs. NYSE/AMEX) since NASDAQ stocks 
may have systematically different returns than non-NASDAQ stocks due to trading costs. ${ }^{3}$ We control for industry to make sure that the common covariance we find is not simply due to common industry shocks. ${ }^{4}$

Second, we want to make sure that the financial constraint factor does not have timevarying characteristics resulting in time-varying factor loadings on the factors of price and book-to-market. We want to be able to estimate the financial constraint factor's loading on various other factors using an OLS regression; this is only valid if the loadings are constant.

As before, we form a factor-mimicking portfolio by taking the returns from a constrained firms portfolio and subtracting the returns from a less constrained firms portfolio. As before, the constrained firm (long) portfolio is the top $20 \%$ of all firms ranked on the financial constraint measure. We form the less constrained firm (short) portfolio by matching, every year, each constrained firm (in the top $20 \%$ ) with a less constrained firm (from the bottom $80 \%$ ) that had the closest possible size and book-to-market measures and which is in the same trading exchange and same industry (see the appendix for details). We call the resulting portfolio FCM, for financial constraints matched. FCM has the same long portfolio as FC, but a different short portfolio.

Table IIB shows summary statistics for the constraint factor, and also shows its correlation with some additional financial return series. First, we include MOMENTUM, a

3 See Loughran (1993). Also, prior to 1975, NASDAQ firms are not included in our sample. If there is a systematic difference between NASDAQ and NYSE/AMEX firms, it may be spuriously reflected by a change in our unmatched return series in 1975. CRSP's records on NASDAQ start in December 1972. As we drop the first two years of a firm's data, NASDAQ stocks first appear in our constraint series in July 1975.

${ }^{4}$ As described in the appendix, we use the Fama and French (1997) scheme based on four digit SIC codes. 
portfolio which measures one-year price momentum (and is formed by sorting stocks on past returns) as in Jegadeesh and Titman (1993) and Carhart (1997). Next, we show TERM and DEFAULT, two bond return series used in Fama and French (1993). TERM is the return on a portfolio of long-term government bonds minus the return on Treasury bills. DEFAULT is the return on a portfolio of corporate bonds minus the return on a portfolio of long-term government bonds.

We should note that comparing the matched factor FCM with these other factors is somewhat unfair, since unlike them FCM has been deliberately purged of many possible sources of return variation. For example, Daniel and Titman (1997) argue that the book-tomarket factor might be spuriously reflecting industry factors, so that its high standard deviation reflects time-varying industry shocks.

Compared with FC, FCM has a slightly larger negative mean and substantially smaller standard deviation. The standard deviation is still large and in the same range as the book-tomarket and size factors. Table IIB shows that both the unmatched and matched constraint factors have positive correlation with the size and market factors, negative correlation with the momentum factor, and small positive correlations with the default factor.

In Table III, we examine the robustness of constraint returns to different matching and inclusion procedures. We try matching by size only (to achieve closer matches along the size dimension). We also try performing this size matching asymmetrically, using strictly smaller firms in the matching portfolio. Compared with the correlations in Table II, these alternative size-matching procedures do not result in a substantial decrease of the correlation between constraint returns and size factor returns. Even the asymmetric size matching procedure 
(which ensures that the long FC portfolio consists of larger firms than the short FC portfolio) results in a return correlation of 0.47 with the size factor. ${ }^{5}$ The positive correlation means that part of the size factor in returns reflects something other than the characteristic of size in the underlying firms.

Table III also shows the effect of matching on book-to-market, size, and exchange only, and then adding the industry matching. We also show the effects of constructing our benchmark matched constraint portfolio (FCM) excluding certain types of firms. We exclude NASDAQ firms, exclude both NASDAQ and AMEX, split the sample into manufacturing and non-manufacturing, exclude very small firms. We also exclude initial public offerings (IPO's) by dropping each firms' first five years of data on CRSP. The results indicate that the negative mean and sizeable standard deviations are not primarily driven by any of these characteristics.

\section{Trends in Financial Constraint Returns}

Figure 2 shows cumulative returns over time on the matched and unmatched constraint factor. From 1968 to about 1979, the unmatched constraint factor earns positive average returns. The matched constraint factor earns negative returns in this period. After 1979, something terrible happened to financially constrained firms' returns. From 1979 to 1995 the losses were 54 basis points per month for the unmatched factor, and 46 points a month for the

s Similarly, Chan and Chen (1991) find that the returns on size-matched portfolios derived from financial characteristics of firms have positive correlations with the size factor. 
matched factor. ${ }^{6}$

For the unmatched factor, the mean of -39 basis points for the whole sample is less than two standard errors from zero; since the matching reduces the standard deviation and decreases the mean, the matched factor's mean of -41 basis points is statistically significant.

These negative unconditional means are surprising on two counts. First, intuition suggests that if aggregate financial constraints are a bad thing, investors should be compensated for holding stocks whose returns positively covary with increases in aggregate financial constraints. Second, from the point of view of existing models, a zero-cost portfolio whose returns are positively correlated with market and size factors should earn positive returns. In the next section, we verify that the average return on the constraint factor does indeed pose a formidable challenge to existing empirical asset pricing models.

\section{Financial Constraint Returns and Asset Pricing}

\section{A. The Negative Mean Return and Previous Results}

Bhandari (1988), Fama and French (1992), Chan and Chen (1991), and Shumway (1996) all find that firms with high measures of leverage, financial distress, or probability of default tend to earn higher returns than other firms. In contrast, we find that financially constrained firms earn lower returns than other firms.

Perhaps the most striking contradiction is with the results from Chan and Chen. Like them, we form size-matched portfolios based on dividend payments and leverage. Chan and

\footnotetext{
6 As noted by Fama and French (1995), small stock returns did particularly badly in the 1980's; one explanation is that small stocks experienced low earnings in the 1980's. Our matched portfolio shows that the characteristic of size is not responsible for FC's big negative returns in the 1980's.
} 
Chen find positive average returns for NYSE size-matched portfolios reflecting dividend payments and leverage. We find large negative average returns. Why are our estimates of mean excess returns so different from Chan and Chen's? One guess is that these differences are due to their different sample period (1956-1985). ${ }^{7}$

A more consistent finding is contained in Fama and French (1993). They find that firms paying zero dividends have returns lower than predicted by their model. Lakonishok, Shleifer, and Vishny (1994) also find that, holding constant book-to-market, firms with lower cash flow and lower earnings tend to have lower returns.

\section{B. Testing for Common Covariation}

We now use the factor-mimicking portfolios to test for common covariation in the returns of all firms. Table I shows the results. We estimate the FC decile portfolios' loadings on the matched constraint factor. If the constraint factor is a pervasive factor in stock returns, then the portfolios should have monotonically increasing loadings on the constraint factor.

Table I shows that the decile portfolios do indeed have (essentially) monotonically increasing loadings on the constraint factor, and we can certainly reject the hypothesis that the portfolios have returns that are uncorrelated with the constraint factor. This means that stocks with higher FC characteristics have higher loadings on the constraint factor, so that there is common covariation that is related to financial constraints. Another way to draw inferences about common covariation within the high FC group is to simply ask whether the variation in the constraint factor can be explained by other empirical factors in stock returns. We next turn

\footnotetext{
${ }^{7}$ Bhandari (1988) studies NYSE firms 1948-1979 and shows that most of the premium earned by leveraged firms is earned prior to 1966 .
} 
to this issue.

\section{Does the constraint factor reflect only known empirical factors?}

As shown in Table IIB, the constraint factor (both matched and unmatched) is correlated with other factors. If the constraint factor is merely a proxy for these other factors, perhaps the mean returns on the constraint factor reflects its loadings on these other factors.

Table IV shows the constraint factor in the context of three other empirical descriptions of the time series of portfolio returns. Table IV show pricing equations that regress the constraint factor on a set of other factor returns. There are two things to look for in this table. First, if these other factors correctly price the constraint factor, the intercept $(\alpha)$ in these regressions should be zero. If the intercept is non-zero, the average return on the constraint factor is not well explained by the other factors. Second, the $\mathrm{R}^{2}$ in these tables measures how much of the variation in the constraint factor can be explained using other systematic factors. If the $\mathrm{R}^{2}$ is low, then the constraint factor measures some independent source of return variance.

We start by discussing the results for the unmatched factor. The first column shows how well the constraint factor can be explained by the CAPM. The constraint factor has a market $\beta$ of 0.45 , which reflects the fact that (from Table I) highly constrained firms have higher $\beta$ 's than less constrained firms. The constraint factor is severely mispriced by the CAPM, with an $\alpha$ of -60 basis points per month.

Next, we attempt to explain the constraint factor with the Fama and French (1993) three-factor model. The severity of the mispricing of the constraint factor increases going from the CAPM to the three-factor model. Mechanically, this occurs because the constraint 
factor has a large positive loading on the size factor but does not have a large positive mean return.

Last, we use the five factors of Fama and French (1993), which includes the two bond market variables measuring term and default returns, and we add a sixth factor, price momentum. The constraint factor has a positive loading on the first three stock market factors, and a negative loading on the bond market factors and price momentum. The sixfactor model has an adjusted $\mathrm{R}^{2}$ of 58 percent.

For the matched factor, the results are similar. The explanatory power of the regressions goes down (as intended), as do the loadings on the size factor. Only $32 \%$ of the variance of the matched constraint factor is explained by the six factor model. We conclude that existing empirical asset pricing models are unable to explain most of the movement in or average level of the constraint factor.

\section{Does the constraint factor price other assets?}

Our results are consistent with Michaely, Thaler, and Womack (1995) on dividend omission drift and with post-earnings announcements drift (see Bernard (1995) for a summary). Since our FC firms have low dividends and low earnings, they may be similar to these omitting firms and so have a "negative drift". One interpretation of our results is that they confirm these "under-reaction" results. Our findings are also similar to Chan, Jegadeesh, and Lakonishok (1996) who examine earnings momentum. Although we do not look at changes in earnings, our high FC firms are likely to be similar to their firms with negative earnings momentum.

Another interpretation is that we have uncovered a factor proxying for a fundamental 
source of risk which determines expected returns. If so, then previous studies are misspecified because they do not properly control for the constraint factor. Thus one could argue that the constraint factor "explains" these anomalies in the same way that the Fama and French (1993) factors explain the size and book-to-market anomalies.

Table V shows the performance of the constraint factor in explaining returns on two portfolios previously identified as anomalous. The table shows three factor pricing equations without the constraint factor, a specification that replaces the size factor with the constraint factor, and a specification which adds the constraint factor to the Fama-French three (we use the matched constraint factor in all cases). Two things are of interest in the table: the $\alpha$ 's, which show whether the use of the constraint factor can eliminate the mispricing; and the loadings on the constraint factor, which show whether the constraint factor shares covariance with these returns, controlling for other sources of covariance.

First we examine returns (in excess of the T-bill returns) from an equal-weight portfolio of recent IPO's (see Ritter (1991) on IPO underperformance). We use 1977-1994 data, taken from Brav and Gompers (1997). In the standard three factor model, IPO's have a large and significantly negative $\alpha$. Using the constraint factor, whether as an addition to or replacement for the size factor, causes the $\alpha$ to move closer to zero and become insignificant. For these two regressions, we use the matched constraint factor measure constructed by excluding IPO's (shown in the last line of Table III). IPO's load positively on the constraint factor, which is reassuring, since presumably IPO firms have relatively low access to capital markets compared to other publicly traded firms.

Next, we examine a equally weighted portfolio of excess returns from firms which have 
recently omitted their dividends, taken from Michaely, Thaler, and Womack (1995). Again, the standard three factor model misprices this portfolio with a large negative $\alpha$. Using the constraint factor, whether as an addition or replacement for the size factor, causes the $\alpha$ to move closer to zero (although in the latter case, the improvement is negligible). In both cases, dividend omitting firms load positively on the constraint factor.

In summary, two corporate finance related anomalies - IPO's and dividend omissions are partially "explained" by the constraint factor. IPO's, dividend omitting firms, and FC firms all share common covariation in their returns, and all have low average returns. All three phenomena may reflect the same underlying causal mechanism.

\section{E. Alternative Explanations}

Many of the plausible explanations for the small firm effect appear to apply to the constraint effect as well. Unfortunately, these explanations all explain why FC firms should have higher than average returns, not lower than average returns. In particular, the survivorship or delisting bias goes in the wrong direction. ${ }^{8}$ The liquidity effect - constrained firms are small, thinly traded, and thus need to earn higher returns to compensate for their illiquidity - also goes the wrong way.

An explanation that at least has the right sign is the dividend tax effect. Since all our FC measures are likely to be correlated with dividend yield, FC maybe just standing in for low dividend and therefore low pre-tax return. Allen and Michaely (1995) survey the literature and conclude (p. 811) that "there is no convincing evidence of a significant cross sectional

\footnotetext{
${ }^{8}$ Table I shows that FC firms have a much higher probability of being delisted from CRSP than other firms. See Shumway (1997) for evidence of the magnitude of the delisting bias.
} 
relationship between stocks' returns and their dividend yields," which argues that the dividend tax effect is an unlikely explanation.

\section{F. Interpretation of Asset Pricing Results}

Our first main result is that there is a constraint factor: financially constrained firms have returns that move together, and this common covariation is not well explained by other factors. We choose to call this common covariation the "financial constraint" factor, but it could equally well be described as the "negative earnings" factor.

Our other main result is that during the sample period, the constraint factor has a negative mean and is mispriced by both the CAPM and multifactor models. There are three possible explanations for this mispricing. All three explanations are economically interesting and merit future research.

First, the constraint factor's low returns could reflect irrationality on the part of market participants. Irrationality is one explanation for stock market anomalies, and we have shown that the constraint factor is related to these anomalies.

Second, it could be that during this period a series of unexpected shocks to future cash flow occurred, surprises that reduced the value of financially constrained firms. As the figures show, negative constraint factor returns occur throughout the 1970's and 1980's for the matched constraint factor, so the surprises must have been fairly evenly spread over time. Under this interpretation, the mispricing of the constraint factor is an anomaly that will not hold out of sample. There is some evidence for this interpretation, since (as discussed in section III.A) other data sets produce different results. This explanation is interesting because the economic source of these cash flow shocks remains an open question. 
Third, perhaps the constraint factor reflects a genuine risk faced by investors, a risk that is not adequately captured by existing multifactor models. Under this interpretation, the constraint factor belongs on the right-hand side of pricing equations, as in Table V. Unlike other empirically identified factors (such as size and book-to-market), the constraint factor has an easily interpretable economic meaning. However, although the existence of an FC premium seems economically understandable, the sign of the premium does not.

Given these concerns, we are reluctant to advocate using the constraint factor as a necessary variable in explaining the cross-section of expected returns. Before doing that, we would want both further out-of-sample robustness checks on the sign of the FC premium, and a theoretical understanding of the link between shocks to financially constrained firms and the marginal utility of investors.

\section{Financial Constraints and Macroeconomic Variables}

The low returns earned by financially constrained firms are puzzling, but not directly relevant for using the financial constraint factor to test economic hypotheses that are unrelated to risk premia. In this section, we use the constructed constraint factor to test for connections between macroeconomic shocks, and financial constraints. Our tests are very simple, and should be regarded as an exploratory investigation.

Table VI shows the monthly correlation of monetary variables, business cycle variables, and returns on portfolios of stocks. The table shows the coefficient on the contemporaneous macroeconomic variable in a univariate regression with stock returns on the left-hand side. If monetary policy and future economic conditions affect the present value of the firm's future earnings, then news about macroeconomic variables should immediately 
affect stock prices. We choose seven macroeconomic variables that are likely reflect innovations in information about current and future economic activity or credit conditions.

We examine two leading indicators of future economic activity. The first is simply the change in $(\log )$ index of leading economic indicators (the LEI, as calculated by the Department of Commerce and the Conference Board). The standard LEI contains a component reflecting aggregate stock returns; we construct an LEI excluding this component. The second is the experimental leading index developed by Stock and Watson (1989).

We examine five measures of monetary policy and credit conditions. The first is an innovation series from Bernanke and Mihov's (1995) analysis of monetary policy and measures changes to Federal Reserve policy. Positive values of this policy shock variable mean looser monetary policy. The second is the change in real M2. The third is the change in the Federal Funds rate. The fourth is the change in the discount rate charged by the Federal Reserve. The fifth is the change in the spread between the 6-month commercial paper rate and the 6-month T-bill rate, used as a measure of credit conditions by Kashyap, Stein and Wilcox (1993).

In Table VI we expect positive correlations of stock returns with the first four macro series (the two leading indicators and the two monetary policy variables), since high growth and looser money are generally considered to be good news for future profits. We expect negative correlations with the last macro three series (all based on interest rates), since higher interest rates and tighter credit conditions are bad news for future profits.

We look at the underlying long and short portfolios of the financial constraint factor, both matched and unmatched. The first column shows the correlation of the returns on highly constrained firms (the long portfolio) and macro variables. The next two columns show the 
same correlations for the less constrained portfolios (the short portfolios), both unmatched and matched for book-to-market, size, trading exchange, and industry. The returns in these three columns are in excess of the T-bill return.

We also show the matched and unmatched constraint factors, which show the difference between the long and short returns, and (for comparison) the market and size factors. The results for the market factor show the correlation of the whole stock market with macro variables. The constraint factor (or the size factor) results show whether highly constrained (or smaller) firms have returns with higher macro correlations than less constrained (or bigger) firms.

Table VI shows that, in general, all types of firms have stock returns that are procyclical and correlated with monetary policy. Columns A-C (for the different classes of FC firms) and column $\mathrm{F}$ (the aggregate stock market) show that all firms have significant correlation with each of the seven macroeconomic variables, with the expected sign. These correlations suggest that we have successfully identified macroeconomic variables that, at the monthly level, contain information about future cash flows. Our simple univariate regression coefficients have power to reject the null hypothesis. Column $G$ shows that small stock returns have higher macroeconomic correlations that large firms, and in five of the seven cases the difference is statistically significant. These results are in line with previous research: aggregate stock returns are correlated with monetary policy, interest rates, and innovations in future economic activity, small stocks more so than large stocks.

Columns A-E of Table VI show that high FC firms have higher correlations of returns than low FC firms. High FC firms have higher return correlations with each of the seven 
variables. Comparing columns $\mathrm{B}$ and $\mathrm{C}$ show that part, but not all, of these higher correlations are due to the non-FC characteristics of these firms, such as their size, industry, etc. Column E shows the differences for the matched portfolios; this column evaluates the hypothesis that (after controlling for various characteristics of firms) more constrained firms are more sensitive to macro variables. These differences are statistically significant in two out of seven cases, and near significant in two more. In sum, Table VI supports the story that financially constrained firms are more affected by aggregate fluctuations, although the evidence is not statistically overwhelming. ${ }^{9}$

We next turn to investigating further the source of these higher sensitivities, by examining leverage effects. By looking only at equity returns, Table VI ignores the fact that the total cash flows generated by the firm are divided between equity and debt. As shown in Table I, high FC firms are highly levered, so their equity is more risky. The economic hypothesis we wish to test is that firm value, not just the value of equity, is correlated with macro variables for financially constrained firms.

The total (unlevered) return on the firm, $\mathrm{r}_{\mathrm{FRM}}$, is reflected in the returns on both debt and equity:

$$
r_{\text {Firm }}=\frac{D}{D+E} r_{D e b t}+\frac{E}{D+E} r_{E q u i t y}
$$

where $D$ and $E$ are the market values of debt and equity. We want to measure $\rho_{\mathrm{FRM}}$, the

9 The results of Table VI are consistent with Table IV, so that one interpretation is that the correlation of the constraint factor and macroeconomic variables is solely due to the fact that the high FC firms have high loadings on the market and size factors, and (as shown in columns F and G) these two factors are correlated with macroeconomic variables. But this interpretation puts the burden of proof on the constraint factor. One might as well claim that the size factor's correlations with macroeconomic variables is due to its loading on the constraint factor. 
regression coefficient of total changes in firm value on a macroeconomic variable. Since covariance is a linear operator, for any such coefficient:

$$
\rho_{\text {Firm }}=\frac{D}{D+E} \rho_{D e b t}+\frac{E}{D+E} \rho_{E q u i t y}
$$

Unfortunately, we do not observe debt returns or the market value of debt for the firms in our sample. To estimate $\rho_{\mathrm{FRM}}$, we therefore assume that the market value of the debt is the book value of the debt (the same assumption underlies Table I's leverage ratios) and that the coefficient $\rho_{D}$ is zero. Wrongly assuming $\rho_{D}$ is zero results in underestimates of the value of $\rho_{\text {PIRM }}$ for firms with high leverage.

We estimate $\rho_{\text {FIRM }}$ by reestimating the correlations in Table VI using the unlevered equity returns. We estimate unlevered equity returns for our various portfolios by, each month, multiplying the observed equity return by the portfolio's $E /(D+E)$ ratio observed in the previous December.

Table VII shows the results. After adjusting for leveraged, high FC firms do not have consistently higher macroeconomic correlations than low FC firms. For the unmatched FC firms, the differences in coefficients have the right sign in only three cases; for the matched, four cases. These differences are all small and statistically insignificant. One interpretation is that the differences in sensitivity shown in Table VI are entirely due to leverage. Another interpretation is that, since our unlevering procedure underestimates $\rho_{\mathrm{FRM}}$ for more levered firms, Table VII underestimates the differences in sensitivity between high and low FC firms.

The truth probably lies somewhere between the results of Table VI and Table VII. Since Table VI itself is not a ringing confirmation of the connection between financial 
constraints and aggregate shocks, the evidence against the null hypothesis is limited at best.

Of course, the correlations we report can never prove that monetary policy is not transmitted through credit constraints. It can only prove that we are unable to identify a portfolio of publicly traded firms relatively highly vulnerable to changes in credit conditions. Our tests are fairly rudimentary, so it is conceivable that more refined testing will reveal interesting connections between the constraint factor and macroeconomic variables.

Lack of monthly correlation between the unlevered constraint factor and macroeconomic variables does not imply that financial constraints are unimportant in terms of economic welfare or policy. If the constraint factor measures aggregate changes in financial constraints, it can be used to identify the shocks to aggregate financial health. For example, FC firms had very low returns in the 1980 's, possible reflecting a negative innovation in future expected earnings of financially constrained firms. The source of this economic shock remains to be identified.

\section{v. Conclusions}

We construct various zero-cost portfolios which are long on financially constrained firms and short on less constrained firms. These portfolios capture common covariation in stock returns not captured by other sources of comovements in stock returns. Thus we conclude that there is a "financial constraint factor," so that a common source of economic shocks to firm value can be detected in stock returns. The evidence suggests that financial constraints do affect firm value, and that the severity of the constraint problem varies over time.

Our investigation of the role of financial constraints in asset pricing reveals a surprising 
result. Using an economically meaningful variable, we reveal major weaknesses in existing multifactor models. Measured any of four different ways, more constrained firms earn lower returns than less constrained firms. Within the context of existing multifactor models, we find no satisfactory explanation for this fact. We also find that some previously identified "anomalies" are related to the financial constraint factor. Firms which have recently had an initial public offering, and firms which have recently omitted their dividend, have returns which are similar to the financial constraint factor.

The evidence for a special relationship between macroeconomic fluctuations and the stock returns of financially constrained firms is weak at best. After accounting for leverage, financially constrained firms do not have returns that are significantly more cyclical than average. Thus the source of the common economic shocks to financial constrained firms remains an open question.

Consider the following explanation of the size effect in asset pricing - the fact that small firms have high returns and have common covariation. Small firms have more precarious access to external finance and are more exposed to variations in credit conditions and to macroeconomic fluctuations generally. Therefore, investors need to be compensated for holding small stocks. This explanation is attractive because it provides an economically meaningful story that is consistent with the following different pieces of evidence: small firms have high returns, are more cyclical, have higher loadings on monetary policy, and tend to be more financial constrained than other firms. Unfortunately, the results in this paper suggests that this explanation is wrong. Unlike small firms, financially constrained firms do not earn high returns. 


\section{Data Appendix}

Table A summarizes the data sources used in this paper.

Our data-selection and portfolio-formation procedures are based on Fama and French (1993). In order for a stock to be included in our sample in a given year $t$, it must meet the following criteria:

1) CRSP classifies the stock as ordinary common equity for a non-financial firm in June of year $t$.

2) It has a CRSP stock price for December of year $t-1$ and June of year $t$.

3) It has at least two years of CRSP and COMPUSTAT data prior to year t.

4) COMPUSTAT has valid information (i.e. neither the missing value or aggregated value flag) on the following annual data items in year t-1: 1 (cash and short-term investments), 6 (liabilities and stockholder's equity-total), 9 (long term debt - total), 14 (depreciation and amortization), 15 (interest expense), 18 (income before extraordinary items), 19 (dividends preferred), 21 (dividends - common), 34 (debt in current liabilities), 60 (common equity total), 74 (deferred taxes - balance sheet), 128 (capital expenditures - flow of funds), 172 (net income), 208 (investment tax credit - balance sheet), and 216 (stockholders' equity - total). We require information on at least one of the following measures of preferred stock outstanding in year t-1: data item 56 (preferred stock - redemption value), 10 (preferred stock - liquidating value), or 130 (preferred stock - par value). As we often use year t-2's capital to deflate particular accounting variables, we require data item 8 (property, plant, and equipment) to be valid and non-zero in year $\mathrm{t}-2$. Finally, we require data item 6 (liabilities and stockholder's equity-total) and the sum of data items 9 (long term debt), 34 (debt in current 
liabilities), and 216 (stockholders' equity - total) to be nonzero as the resulting values are in the denominator of ratios used in the construction of the Kaplan-Zingales Index (see below).

For each year $t$ in which a stock is selected, we obtain from CRSP the stock's exchange (NYSE, AMEX or NASDAQ), SIC code for industry categorization, market capitalization for December of year $\mathrm{t}-1$ and June of year $\mathrm{t}$, and monthly returns for the 12 months from July of $\mathrm{t}$ through June of $t+1$. Thus we allow a minimum of six months between fiscal year end and the subsequent return data for the portfolio. This precaution is necessary as approximately one-fifth of all firms fail to file their 10-K reports with the SEC within 90 days of their fiscal year end (see Fama and French (1992)).

We obtain firm level accounting variables from the annual expanded COMPUSTAT file maintained at the Center for Research in Securities Prices at the University of Chicago Graduate School of Business. This file is a merging of several COMPUSTAT current and historical files, including current and back data annual files for Full Coverage, Primary-Supplementary-Tertiary, Merged Research, and Canadian subsets. From this database we obtain the accounting information necessary to form our measures of financial constraint for the fiscal year ending in calendar year $\mathrm{t}-1$.

Our return series begin in July 1968, based on accounting data from December 1967. Although we have access to reliable COMPUSTAT data going back to 1962 , the number of firms in the period 1963-1967 which meet the selection criteria is very small (the total universe of such firms contains only 61 observations in 1963).

We measure to what degree a firm is financially constrained using Net Cash Flow, the Kaplan-Zingales Index, Interest Coverage, Dividend Payout, and the composite FC measure. 
These measures are defined below. Item numbers refer to COMPUSTAT annual data items described above. Also note that data item 8 is used to deflate particular stock variables. As such, we always lag it one year.

Net Cash Flow. NCF=(Item 128-Item 18-Item 14)/Item 8

Kaplan-Zingales Index. $\mathrm{KZ}=-1.001909 *[($ Item $18+$ Item 14)/Item 8$]+.2826389 *[($ Item 6+CRSP December Market Equity-Item 60-Item 74)/Item 6]+3.139193*[(Item 9+Item 34)/(Item 9+Item 34+Item 216)] -39.3678*[(Item 21+Item 19)/Item 8]-1.314759*[Item 1/Item 8] Kaplan and Zingales (1997) also use three variables (dividend restrictions, unused lines of credit, and unrestricted earnings) which they collected by hand and which are not available on COMPUSTAT. The authors kindly re-estimated their ordered logit without these variables, and without year dummies, producing the weights for the index.

Interest Coverage Ratio. We rank all firms with nonpositive Item 18 in order of decreasing [(Item 15-Item 18)/Item 8]. We then rank all firms with positive Item 18 and positive Item 15 in increasing order of [(Item 18+Item 15)/Item 15]. Finally all firms with positive Item 18 and nonpositive Item 15 are ranked in decreasing order of [(Item 15-Item 18)/Item 8].

Dividend Payout. We rank all firms with zero [Item 21+Item 115] in increasing [Item 172/Item 8] order, then all firms with nonzero [Item 21+Item 115] and nonpositive Item 172 in increasing [Item 172/Item 8] order. Finally all firms with nonzero [Item 21+ltem 115] and positive Item 172 in increasing [(Item $21+$ Item 115)/Item 172] order.

FC. We rank all firms on the four criteria of NCF, KZ, IC and D/E. We average their percentile rankings to construct a composite financial constraints measure.

When sorting firms by any of these firm measures into either deciles or quintiles, we use 
market breakpoints. Fama and French $(1992,1993)$ use NYSE breakpoints when sorting firms by size or BE/ME. Their method ensures that the many small stocks on NASDAQ do not dominate breakpoint calculations and heavily tilt the allocation of total market capitalization to a few portfolios. Though our measures of financial constraint are correlated with size, we do not report results using NYSE breakpoints as our subsequent aggregation of these measures into a single FC ranking requires a percentile ranking for all stocks for each of the four measures.

The financial constraint return series are constructed by first ranking all firms in a given year on the constraint measure (NCF, $\mathrm{KZ}, \mathrm{IC}, \mathrm{D} / \mathrm{E}$, or FC) from less constrained (low) to more constrained (high) and then subtracting the returns on a value-weight portfolio of the lowest $20 \%$ (the short portfolio) from the returns on a value-weight portfolio of the highest $20 \%$ (the long portfolio).

We also form matched financial constraint factors by constructing the short portfolio as a matching portfolio. For example, to form the size and book-to-market matched portfolio, we use the following algorithm. First, we rank all firms in each year by financial constraint, size, and book to market, and assign each firm a percentile ranking on each dimension. Then, for each firm in the upper $20 \%$ of the financial constraint measure, we find a matching firm from the lower $80 \%$ that is closest in terms of size and book-to-market. To determine the closest firm, we first search among firms within $1 \%$ of the size and book-to-market of the target firm. If such a firm exists, we use it to match. If such a firm did not exist, we widen the band to within $2 \%$ along both dimensions, and so on. We did this for each firm in each year, sampling without replacement from the lower $80 \%$ to match the top $20 \%$. In the case of ties (more than one matching firm within $\mathrm{x} \%$ of size and book to market) we use the matching firm with the lowest financial constraint 
measure. The short portfolio is the value-weight portfolio of these matching firms. We form the short portfolios for the size-matched and asymmetric-size-matched portfolios in a similar manner.

When we also exchange match our financially constrained firms, we restrict the size and book-to-market matching procedure to the subset of the lower $80 \%$ that are on the same exchange as the particular firm in question at the time of portfolio formation. Then we find a matching firm from the lower $80 \%$ that is closest in terms of size and book-to-market using the same procedure as before.

When we industry-match as well as exchange match, we restrict the size and book-tomarket matching procedure to the subset of the lower $80 \%$ that are on the same exchange and in the same industry as the particular firm in question at the time of portfolio formation. We use the same classification of four-digit SIC codes into 48 industries as Fama and French (1997). A brief examination of the industry composition (at the level of aggregation of the one-digit SIC code) of the high FC firms did not reveal any obvious pattern. 


\section{References}

Allen, Franklin, and Roni Michaely, 1995, Dividend policy, in Jarrow, R.A., V. Maksimovic, and W.T. Ziemba, eds: Finance (Elsevier, Amsterdam).

Bernanke, Ben, and Mark Gertler, 1989, Agency costs, net worth, and business fluctuations, American Economic Review 79, 14-31.

Bernanke, Ben, Mark Gertler, and Simon Gilchrist, 1996, The financial accelerator and the flight to quality, Review of Economics and Statistics 78, 1-15.

Bernanke, Ben, and Ilian Mihov, 1995, Measuring monetary policy, NBER Working Paper No. 5145 .

Bernard, Victor L., 1993, Stock price reactions to earnings announcements, in Thaler, Richard H., ed: Advances in Behavioral Finance (Russell Sage, New York).

Bhandari, Laxmi Chand, 1988, Debt/equity ratio and expected common stock returns: Empirical evidence, Journal of Finance 43, 507-528.

Brav, Alon and Paul A. Gompers, 1997, Myth or reality? The long-run performance of initial public offerings: Evidence from venture and nonventure capital-backed companies, working paper, Harvard University.

Carhart, Mark M., 1997, On the persistence of mutual fund performance, Journal of Finance 52, $57-82$.

Chan, K. C. and Nai-fu Chen, 1991, Structural and return characteristics of small and large firms, Journal of Finance 46, 1467-1484.

Chan, Louis K.C., Narasimhan Jegadeesh, and Josef Lakonishok, 1996, Momentum strategies, Journal of Finance 51, 1681-1714.

Daniel, Kent and Sheridan Titman, 1997, Evidence on the characteristics of cross sectional variation in stock returns, Journal of Finance 52, 1-34.

Fama, Eugene F. and Kenneth R. French, 1992, The cross-section of expected stock returns, Journal of Finance 47, 427-465.

Fama, Eugene F. and Kenneth R. French, 1993, Common risk factors in the returns on stocks and bonds, Journal of Financial Economics 33, 3-56.

Fama, Eugene F. and Kenneth R. French, 1995, Size and book-to-market factors in earnings and 
returns, Journal of Finance 50, 131-155.

Fama, Eugene F. and Kenneth R. French, 1997, Industry costs of equity, Journal of Financial Economics 43, 153-194.

Fazzari, Steven, R. Glenn Hubbard, and Bruce Petersen, 1988, Financing constraints and corporate investment, Brookings Papers on Economic Activity, 141-195.

Gertler, Mark and Simon Gilchrist, 1994, Monetary policy, business cycles, and the behavior of small manufacturing firms, Quarterly Journal of Economics 109, 565-592.

Gertler, Mark, and R. Glenn Hubbard, 1988, Financial factors in business fluctuations, in Financial Market Volatility (Federal Reserve Bank of Kansas City, Kansas City, MO).

Jegadeesh, Narasimhan and Sheridan Titman, 1993, Returns to buying winners and selling losers: Implications for stock market efficiency, Journal of Finance 48, 65-91.

Kaplan, Steven N., and Luigi Zingales, 1997, Do financing constraints explain why investment is correlated with cash flow?, Quarterly Journal of Economics 112, 168-216.

Kashyap, Anil K., Owen A. Lamont, and Jeremy C. Stein, 1994, Credit conditions and the cyclical behavior of inventories, Quarterly Journal of Economics 109, 565-592.

Kashyap, Anil K., Jeremy C. Stein, and David Wilcox, 1993, Monetary policy and credit conditions: Evidence from the composition of external finance, American Economic Review 83, 78-98.

Keim, Donald B. and Robert F. Stambaugh, 1986, Predicting returns in the stock and bond market, Journal of Financial Economics 17, 357-390.

Lakonishok, Josef, Andrei Shleifer, and Robert W. Vishny, 1994, Contrarian investment, extrapolation, and risk, Journal of Finance 49, 1541-1578.

Loughran, Tim, 1993, NYSE vs. NASDAQ returns: Market microstructure or poor performance of Initial Public Offerings?, Journal of Financial Economics 33, 241-260.

Michaely, Roni, Richard H. Thaler, and Kent L. Womack, 1995, Price reaction to dividend initiations and omissions: overreaction or drift?, Journal of Finance 50, 573-608.

Shumway, Tyler, 1996, The Premium for default risk in stock returns, University of Chicago Graduate School of Business Ph.D. thesis.

Shumway, Tyler, 1997, The delisting bias in CRSP data,, Journal of Finance 52, 327-340. 
Stock, James, and Mark W. Watson, 1989, ,New indexes of coincident and leading economic indicators, in Blanchard, Olivier Jean Blanchard and Stanley Fischer, eds: NBER Macroeconomics Annual 1989 (University of Chicago Press, Chicago).

Thorbecke, Willem, 1997, On stock market returns and monetary policy, Journal of Finance 52, 635-654.

Ritter, Jay, 1991, The long-run performance of initial public offerings, Journal of Finance 42, 365-394. 
Table I

Portfolio Characteristics and Covariance Tests

1968-1995

\section{Portfolio Characteristics}

Value Weighted

Monthly Returns CAPM $\beta$ Market Dividend- Earnings- Book-to

(pre- Debt to-price to-price -Market

Mean Std formation) Ratio Ratio Ratio

\section{Percent}

low FC
2
3
4
5
6
7
8
9

high FC
$1.10 \quad 4.64$

$1.05 \quad 4.75$

$1.10 \quad 4.78$

$1.12 \quad 4.69$

$1.05 \quad 4.91$

$0.93 \quad 4.71$

$0.89 \quad 5.13$

$0.90 \quad 6.16$

$0.88 \quad 7.43$

$0.32 \quad 8.52$

\begin{abstract}
Percent Percent
\end{abstract}
------Equal Weighted------

Size NASDAQ Probability

(Mkt Fraction of delisting

Cap) 1975-95 (subsequent)

\section{Covariance}

FC LOAD

Coef T- $R^{2}$

Stat

\section{(bil \$) Percent Percent}

$\begin{array}{ccccccccccc}0.95 & 5.36 & 3.12 & 6.86 & 0.36 & 0.81 & 47 & 7.08 & 0.47 & 5.78 & 0.09 \\ 1.04 & 13.71 & 3.03 & 8.04 & 0.50 & 0.77 & 46 & 7.47 & 0.51 & 6.28 & 0.10 \\ 1.00 & 20.73 & 3.91 & 9.97 & 0.72 & 0.88 & 42 & 7.70 & 0.50 & 6.02 & 0.10 \\ 0.95 & 25.86 & 4.19 & 9.97 & 0.81 & 0.77 & 40 & 7.50 & 0.55 & 6.95 & 0.13 \\ 0.99 & 31.72 & 4.51 & 9.86 & 0.87 & 0.58 & 42 & 6.89 & 0.59 & 7.09 & 0.13 \\ 0.96 & 36.74 & 4.25 & 8.97 & 0.89 & 0.48 & 47 & 7.64 & 0.54 & 6.77 & 0.12 \\ 1.09 & 42.43 & 4.28 & 4.81 & 0.91 & 0.26 & 53 & 8.11 & 0.67 & 7.89 & 0.16 \\ 1.31 & 42.64 & 2.46 & 0.33 & 0.81 & 0.14 & 58 & 9.19 & 0.97 & 9.83 & 0.23 \\ 1.46 & 40.43 & 1.18 & -9.08 & 0.77 & 0.08 & 64 & 10.40 & 1.60 & 15.76 & 0.43 \\ 1.60 & 40.42 & 0.49 & -29.60 & 0.61 & 0.03 & 72 & 15.00 & 1.86 & 16.09 & 0.44\end{array}$




\section{Notes to Table I}

This table reports summary statistics, from July 1968 to December 1995, for ten value-weight portfolios formed by ranking in each June of year $t$ all NYSE-AMEX-NASDAQ firms with the available COMPUSTAT accounting information on our composite financial constraint characteristic. We report the sample mean and standard deviation of each portfolio's monthly nominal return. Pre-formation CAPM $b$ is the portfolio average of each firm's market model $b$ estimated using at most three and at least two years of pre-formation monthly returns. We report the average, across each year, of four accounting ratios for each portfolio: market debt ratio, dividend-to-price ratio, earnings-to-price ratio, and book-to-market. We calculate these accounting measures as the portfolio average of each individual firm's measure. Market debt is the ratio of long and short term debt to the sum of long and short term debt and the December t-1 market capitalization. Dividend-to-price is the ratio of the sum of common and preferred dividends to December t-1 market capitalization. Earnings-to-price is the ratio of the sum of income before extraordinary items plus income statement deferred taxes minus preferred dividends to December $\mathrm{t}-1$ market capitalization. We compute book-to-market for each firm as the ratio of the sum of stockholders equity plus deferred taxes plus investment tax credit minus preferred stock to December t-1 market capitalization. Size is the equal-weight average of June $t$ market capitalization, in billions of nominal dollars. We report the percentage of stocks in each decile that are listed on NASDAQ in June t for the July 1975 to December 1995 subperiod. We also report the average percentage across time of stocks in each decile which delist each year in the 12 months subsequent to portfolio formation. Finally, we regress the returns on each portfolio on the returns on our FCM factor. We report each regression coefficient, and the associated t-statistic and adjusted $R^{2}$. 
Table II

Summary Statistics for Factor Returns Monthly Percent Returns 68:7-95:12 (330 months)

A. Factor-mimicking portfolio returns: four underlying measures, combined financial constraint factor, and other portfolio returns

NCF KZ IC D/E FC RM-RF HML SMB

Correlation Matrix

$\begin{array}{lrrrrrrrr}\text { NCF } & 1.00 & 0.65 & 0.67 & 0.60 & 0.72 & 0.18 & 0.07 & 0.47 \\ \text { KZ } & 0.65 & 1.00 & 0.66 & 0.73 & 0.84 & 0.38 & -0.06 & 0.60 \\ \text { IC } & 0.67 & 0.66 & 1.00 & 0.71 & 0.82 & 0.33 & 0.20 & 0.73 \\ \text { D/E } & 0.60 & 0.73 & 0.71 & 1.00 & 0.89 & 0.51 & -0.33 & 0.77 \\ \text { FC } & 0.72 & 0.84 & 0.82 & 0.89 & 1.00 & 0.43 & -0.06 & 0.72 \\ \text { RM-RF } & 0.18 & 0.38 & 0.33 & 0.51 & 0.43 & 1.00 & -0.39 & 0.31 \\ \text { HML } & 0.07 & -0.06 & 0.20 & -0.33 & -0.06 & -0.39 & 1.00 & -0.11 \\ \text { SMB } & 0.47 & 0.60 & 0.73 & 0.77 & 0.72 & 0.31 & -0.11 & 1.00\end{array}$

Other Summary Statistics

$\begin{array}{lrrrrrrrr}\text { Mean } & -0.59 & -0.15 & -0.16 & -0.42 & -0.39 & 0.45 & 0.46 & 0.10 \\ \text { Std Dev } & 3.38 & 3.87 & 4.87 & 5.64 & 4.86 & 4.55 & 2.66 & 2.80 \\ \text { Min } & -11.78 & -11.50 & -10.91 & -17.73 & -14.97 & -22.77 & -9.96 & -9.79 \\ \text { Max } & 13.47 & 15.25 & 22.59 & 20.32 & 16.01 & 16.19 & 8.92 & 10.81\end{array}$

B.Factor-mimicking portfolio returns: combined financial constraint, matched (FCM) and unmatched $(\mathrm{FC})$, and other portfolio returns

Correlation Matrix

\section{FC FCM RM-RF HML SMB MOMENTUM TERM DEFAULT}

$\begin{array}{lrrrrrrrr}\text { FC } & 1.00 & 0.75 & 0.43 & -0.06 & 0.72 & -0.34 & -0.04 & 0.11 \\ \text { FCM } & 0.75 & 1.00 & 0.38 & -0.14 & 0.49 & -0.32 & -0.01 & 0.11 \\ \text { RM-RF } & 0.43 & 0.38 & 1.00 & -0.39 & 0.31 & -0.01 & 0.36 & 0.00 \\ \text { HML } & -0.06 & -0.14 & -0.39 & 1.00 & -0.11 & -0.16 & -0.05 & 0.09 \\ \text { SMB } & 0.72 & 0.49 & 0.31 & -0.11 & 1.00 & -0.40 & -0.09 & 0.13 \\ \text { MOMENTUM } & -0.34 & -0.32 & -0.01 & -0.16 & -0.40 & 1.00 & 0.13 & -0.20 \\ \text { TERM } & -0.04 & -0.01 & 0.36 & -0.05 & -0.09 & 0.13 & 1.00 & -0.45 \\ \text { DEFAULT } & 0.11 & 0.11 & 0.00 & 0.09 & 0.13 & -0.20 & -0.45 & 1.00 \\ \text { Other Summary } & \text { Statistics } & & & & & & & \\ \text { Mean } & -0.39 & -0.41 & 0.45 & 0.46 & 0.10 & 0.84 & 0.19 & 0.01 \\ \text { Std Dev } & 4.86 & 3.05 & 4.55 & 2.66 & 2.80 & 3.50 & 3.13 & 1.26 \\ \text { Min } & -14.97 & -11.09 & -22.77 & -9.96 & -9.79 & -19.52 & -9.28 & -5.14 \\ \text { Max } & 16.01 & 14.31 & 16.19 & 8.92 & 10.81 & 12.27 & 13.98 & 4.56 \\ \text { Autocorrelation } & 0.17 & 0.13 & 0.05 & 0.21 & 0.15 & -0.02 & 0.06 & -0.19\end{array}$




\section{Notes to Table II}

This table presents summary statistics for the monthly factor mimicking portfolio returns for financial constraints and for six other factors used in previous research. All data are monthly percent returns, July 1968 to December 1995 (330 observations).

The financial constraint return series are constructed by ranking all firms in a given year, and subtracting the returns on a value-weight portfolio of less constrained firms (the short portfolio) from the returns on a value-weight portfolio of highly constrained firms (the long portfolio). The four measures of financial constraint are as follows. NCF is net cash flow. $\mathrm{KZ}$ is the Kaplan and Zingales index. IC is interest coverage. D/E is dividend payout. FC is the combined (unmatched) financial constraints factor, constructed by combining the ranking of each firm on the four criteria of NCF, KZ, IC and $\mathrm{D} / \mathrm{E}$, and using this combined ranking to construct a composite financial constraints measure. FCM is the financial constraint factor matched for book-to-market, size, trading exchange, and industry. See the Appendix for details of the data-selection and portfolio-formation procedures.

The following five factors come from Fama and French (1993): RM-RF, the market factor, is the return on a value-weighted portfolio of NYSE/AMEX/NASDAQ stocks minus the return on a portfolio of Treasury bills. HML is high minus low, which measures the book-to-market factor by subtracting returns from a portfolio of high book-to-market firm stocks from the returns from a portfolio of low book-to-market firm stocks. SMB is small minus big, which measures the size factor by subtracting returns from a portfolio of big firm stocks from the returns from a portfolio of small firm stocks. TERM is the return on a portfolio of long-term government bonds minus the return on Treasury bills. DEFAULT is the return on a portfolio of corporate bonds minus the return on a portfolio of long-term government bonds.

MOMENTUM measures price momentum, and is a portfolio return constructed by subtracting the returns from a portfolio experiencing low returns in the past 11 months from the returns of a portfolio experiencing high returns in the past 11 months, 1968:7-1995:12. 
Table III

Alternative measures of the FC factor-mimicking portfolios

This table shows the effects on our main results of different matching and exclusion rules used in constructing the constraint factor. We show the summary statistics for the monthly returns on constraint factor mimicking portfolios from July 1968 to December 1995 (330 observations). The matched factors use the top $20 \%$ of all firms ranked on the combined FC characteristic, and pick similar firms from the bottom $80 \%$. "No. of Obs." is the number of underlying observations (stock-years), 1968-1995, used as potential candidates to select firms for the factor mimicking portfolio. Manufacturing firms have SIC code 20-39. "No IPO's" excludes the first five years of CRSP data.

Unmatched (FC)

Matched by Size Only

Asymmetric Size Matching: Matching

With Smaller Firms

Matched by Book-to-market, Size, and Exchange
Matched by Industry (FCM)
Excluding NASDAQ
Excluding NASDAQ and AMEX
Manufacturing Firms Only
Nonmanufacturing Firms Only
Excluding 5\% Smallest Firms Every Year
No Initial Public Offerings
Returns Correlation with No. of Obs., Mean Std. FC FCM Thousands
Dev

$\begin{array}{lllll}-0.39 & 4.86 & 1.00 & 0.75 & 75 \\ & & & & \\ -0.60 & 3.73 & 0.88 & 0.78 & 75 \\ -0.56 & 3.71 & 0.87 & 0.78 & 75\end{array}$

$\begin{array}{lllll}-0.60 & 3.22 & 0.82 & 0.73 & 75 \\ -0.41 & 3.05 & 0.75 & 1.00 & 75 \\ -0.29 & 2.71 & 0.56 & 0.69 & 40 \\ -0.28 & 2.45 & 0.49 & 0.53 & 26 \\ -0.30 & 3.70 & 0.60 & 0.67 & 40 \\ -0.73 & 3.65 & 0.52 & 0.70 & 35 \\ -0.46 & 2.96 & 0.70 & 0.94 & 71 \\ -0.41 & 2.90 & 0.74 & 0.93 & 71\end{array}$


Table IV

Pricing Tests

This table shows OLS regression results with constraint factor as the dependent variable. $\alpha$ is the constant term. All variables are defined in Table II. Monthly Data 68:7-95:12 (330 months)

CAPM

$\underline{\text { FF three-factor }}$

Coef. T-statistic Coef. T-statistic Coef T-statistic
FF five-factor plus

Price Momentum

\section{A. Dependent variable: Unmatched Constraint Factor, FC}

$\alpha$

RM-RF

HML

SMB

TERM

DEF

MOMENTUM

$$
\begin{array}{r}
-0.60 \\
0.45
\end{array}
$$$$
-2.44
$$

8.51

$-0.72$

0.28

0.20

1.13

13

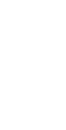

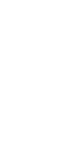

$$
\begin{array}{r}
-4.00 \\
6.48 \\
2.86 \\
17.19
\end{array}
$$$$
-0.61
$$

0.35

0.21

1.04

14.21

$-0.18$

$-2.56$

$-0.19$

$-1.17$

$-0.11$

$-2.02$

R-bar-2

0.18

0.57

0.58

\section{B. Dependent variable: Matched Constraint Factor, FCM}

$\begin{array}{lrrrrrr}\alpha & -0.52 & -3.32 & -0.52 & -3.57 & -0.36 & -2.37 \\ \text { RM-RF } & 0.25 & 7.39 & 0.17 & 4.70 & 0.19 & 4.85 \\ \text { HML } & & & 0.00 & -0.06 & -0.04 & -0.67 \\ \text { SMB } & & & 0.44 & 8.33 & 0.34 & 5.77 \\ \text { TERM } & & & & & -0.05 & -0.96 \\ \text { DEF } & & & & & 0.02 & 0.14 \\ \text { MOMENTUM } & & & & & -0.17 & -3.75\end{array}$

R-bar-2

0.14

0.29

0.32 
Table V

Financial Constraint Returns and Other Assets

This table shows the coefficients and t-statistics in a regression of portfolio returns on the Fama-French three factors and on the matched constraint factor (FCM) returns. The first column excludes IPO's when constructing FC returns (as shown in Table III). IPO: A equally-weighted portfolio consisting of firms who in the last five years have had an initial public offering, 1977:1-1994:12. DIVIDEND OMISSIONS: A equally-weighted portfolio consisting of firms who in the last three years have omitted a dividend. There are 885 total firms over the sample period, 1965:5-1990:11.

\begin{tabular}{|c|c|c|c|c|}
\hline & Initial Pub & Offerings & Dividend $\mathrm{C}$ & iissions \\
\hline & Coef. & T-statistic & Coef. & T-statistic \\
\hline$\alpha$ & -0.35 & -2.21 & -0.60 & -3.19 \\
\hline RM-RF & 0.98 & 24.15 & 1.13 & 25.92 \\
\hline HML & -0.24 & -3.38 & 0.73 & 10.00 \\
\hline SMB & 1.22 & 19.16 & 1.55 & 23.16 \\
\hline R-bar-2 & 0.88 & & 0.87 & \\
\hline$\alpha$ & 0.32 & 1.39 & -0.22 & -0.72 \\
\hline RM-RF & 1.00 & 16.88 & 1.26 & 18.06 \\
\hline HML & -0.35 & -3.47 & 0.79 & 6.90 \\
\hline FCM & 0.70 & 8.53 & 0.80 & 7.50 \\
\hline R-bar-2 & 0.76 & & 0.68 & \\
\hline$\alpha$ & -0.14 & -0.89 & -0.49 & -2.59 \\
\hline RM-RF & 0.94 & 24.13 & 1.10 & 24.63 \\
\hline HML & -0.26 & -3.97 & 0.73 & 10.17 \\
\hline SMB & 1.08 & 16.80 & 1.47 & 20.37 \\
\hline FCM & 0.33 & 5.61 & 0.21 & 2.84 \\
\hline R-bar-2 & 0.90 & & 0.87 & \\
\hline
\end{tabular}


Table VI

Contemporaneous Relationship of Macro Variables and Stock Returns

This table reports contemporaneous correlation coefficients from a univariate regression of monthly stock returns on a single macro variable. For each portfolio return series, the table reports the coefficient $b$ from the equation: $R=a+b * M A C R O+\epsilon$

Columns A-C have as dependent variables monthly percent returns in excess of the T-bill return.

LEI is the index of leading economic indicators prepared by The Conference Board (formerly produced by the Department of Commerce), adjusted to exclude the stock price component of the index. XLI is the Stock and Watson (1989) experimental leading indicator, which is expressed in units of forecast percent change in economic activity. Bernanke-Mihov shock is a time series of innovations to the Federal Reserve reaction function, and ends in 1994:12. Positive values of the shock mean looser monetary policy. The CP spread is the difference hetween the commercial paper yield and the 6-month T-bill yield.

All series are expressed in percent terms. Monthly Data 68:7-95:12 (330 months)

\begin{tabular}{|c|c|c|c|c|c|c|c|}
\hline & $\bar{A}$ & B & $\mathrm{C}$ & $\begin{array}{c}\mathrm{D}= \\
\mathrm{A} \text { minus B }\end{array}$ & $\begin{array}{c}E= \\
A \text { minus } C\end{array}$ & $F$ & G \\
\hline Measure & $\begin{array}{l}\text { High FC } \\
\text { Firms } \\
\text { (Long } \\
\text { Portfolio) }\end{array}$ & $\begin{array}{l}\text { Low F } \\
\text { (Short } \\
\text { Raw }\end{array}$ & $\begin{array}{l}\text { C Firms } \\
\text { Portfolio) } \\
\text { Matched }\end{array}$ & $\begin{array}{c}\text { Unmatched } \\
\text { Constraint } \\
\text { Factor } \\
\text { FC }\end{array}$ & $\begin{array}{c}\text { Matched } \\
\text { Constraint } \\
\text { Factor } \\
\text { FCM }\end{array}$ & RM-RF & SMB \\
\hline$\Delta \ln ($ LEI Index $)$ & $\begin{array}{r}3.41 \\
(3.06)\end{array}$ & $\begin{array}{r}1.61 \\
(2.33)\end{array}$ & $\begin{array}{r}2.24 \\
(2.56)\end{array}$ & $\begin{array}{r}1.80 \\
(2.48)\end{array}$ & $\begin{array}{r}1.17 \\
(2.58)\end{array}$ & $\begin{array}{r}1.63 \\
(2.41)\end{array}$ & $\begin{array}{r}1.28 \\
(3.07)\end{array}$ \\
\hline$\Delta \mathrm{XLI}$ Index & $\begin{array}{r}1.04 \\
(2.96)\end{array}$ & $\begin{array}{r}0.57 \\
(2.65)\end{array}$ & $\begin{array}{r}0.78 \\
(2.84)\end{array}$ & $\begin{array}{c}0.46 \\
(2.03)\end{array}$ & $\begin{array}{r}0.26 \\
(1.81)\end{array}$ & $\begin{array}{r}0.53 \\
(2.49)\end{array}$ & $\begin{array}{r}0.27 \\
(2.06)\end{array}$ \\
\hline Bernanke-Mihov shock & $\begin{array}{r}1.19 \\
(2.56)\end{array}$ & $\begin{array}{r}0.78 \\
(2.72)\end{array}$ & $\begin{array}{r}0.99 \\
(2.73)\end{array}$ & $\begin{array}{c}0.41 \\
(1.37)\end{array}$ & $\begin{array}{r}0.20 \\
(1.05)\end{array}$ & $\begin{array}{r}0.93 \\
(3.31)\end{array}$ & $\begin{array}{r}0.13 \\
(0.77)\end{array}$ \\
\hline$\Delta \ln ($ Real M2) & $\begin{array}{r}2.68 \\
(3.27)\end{array}$ & $\begin{array}{r}1.82 \\
(3.61)\end{array}$ & $\begin{array}{r}2.06 \\
(3.21)\end{array}$ & $\begin{array}{c}0.87 \\
(1.61)\end{array}$ & $\begin{array}{r}0.63 \\
(1.86)\end{array}$ & $\begin{array}{r}1.72 \\
(3.47)\end{array}$ & $\begin{array}{r}1.09 \\
(3.55)\end{array}$ \\
\hline$\Delta$ Fed Funds Ratc & $\begin{array}{r}-1.46 \\
(2.60)\end{array}$ & $\begin{array}{r}-1.25 \\
(3.63)\end{array}$ & $\begin{array}{r}-1.34 \\
(3.06)\end{array}$ & $\begin{array}{l}-0.22 \\
(0.59)\end{array}$ & $\begin{array}{r}-0.12 \\
(0.53)\end{array}$ & $\begin{array}{r}-1.23 \\
(3.65)\end{array}$ & $\begin{array}{r}-0.33 \\
(1.56)\end{array}$ \\
\hline$\Delta$ Discount Rate & $\begin{array}{r}-5.16 \\
(3.39)\end{array}$ & $\begin{array}{r}-4.02 \\
(4.34)\end{array}$ & $\begin{array}{r}-4.35 \\
(3.67)\end{array}$ & $\begin{array}{l}-1.14 \\
(1.14)\end{array}$ & $\begin{array}{r}-0.81 \\
(1.29)\end{array}$ & $\begin{array}{r}-3.79 \\
(4.15)\end{array}$ & $\begin{array}{r}-1.33 \\
(2.32)\end{array}$ \\
\hline$\Delta C P$ Spread & $\begin{array}{r}-6.33 \\
(4.01) \\
\end{array}$ & $\begin{array}{r}-3.08 \\
(3.14) \\
\end{array}$ & $\begin{array}{r}-4.43 \\
(3.57)\end{array}$ & $\begin{array}{l}-3.25 \\
(3.15)\end{array}$ & $\begin{array}{r}-1.91 \\
(2.94) \\
\end{array}$ & $\begin{array}{r}-2.92 \\
(3.02) \\
\end{array}$ & $\begin{array}{r}-2.22 \\
(3.76) \\
\end{array}$ \\
\hline
\end{tabular}


Table VII

Contemporaneous Relationship of Macro Variables and Unlevered FC Returns

This table reports contemporaneous correlation coefficients from a univariate regression of monthly stock returns on a single macro variable. The stock returns have been unlevered by multiplying each excess return by the ratio of the market value of equity to the total market value of the firm. Total market value is defined as the market value of equity plus the book value of debt, and is updated every July to reflect the previous December's observed value. For each portfolio return series, the table reports the coefficient $b$ from the equation: $R=a+b * M A C R O+\epsilon$

Columns A-C have as dependent variables monthly percent returns in excess of the T-bill return.

LEI is the index of leading economic indicators prepared by The Conference Board (formerly produced by the Department of Commerce), adjusted to exclude the stock price component of the index. XLI is the Stock and Watson (1989) experimental leading indicator, which is expressed in units of forecast percent change in economic activity. Bernanke-Mihov shock is a time series of innovations to the Federal Reserve reaction function, and ends in 1994:12. Positive values of the shock mean looser monetary policy. The CP spread is the difference between the commercial paper yield and the 6-month T-bill yield. All series are expressed in percent terms. Monthly Data 68:7-95:12 (330 months)

\begin{tabular}{|c|c|c|c|c|c|}
\hline & A & B & $\mathrm{C}$ & $\begin{array}{c}\mathrm{D}= \\
\mathrm{A} \text { minus } \mathrm{B}\end{array}$ & $\begin{array}{c}E= \\
A \text { minus } C\end{array}$ \\
\hline Measure & $\begin{array}{c}\text { High FC } \\
\text { Firms } \\
\text { (Long } \\
\text { Portfolio) }\end{array}$ & $\begin{array}{l}\text { Low F } \\
\text { (Short } \\
\text { Raw }\end{array}$ & $\begin{array}{l}\text { C Firms } \\
\text { Portfolio) } \\
\text { Matched }\end{array}$ & $\begin{array}{l}\text { Unmatched } \\
\text { Constraint } \\
\text { Factor } \\
\text { FC }\end{array}$ & $\begin{array}{c}\text { Matched } \\
\text { Constraint } \\
\text { Factor } \\
\text { FCM }\end{array}$ \\
\hline$\Delta \ln ($ LEI Index $)$ & $\begin{array}{r}1.87 \\
(2.75)\end{array}$ & $\begin{array}{r}1.47 \\
(2.36)\end{array}$ & $\begin{array}{r}1.54 \\
(2.34)\end{array}$ & $\begin{array}{r}0.40 \\
(0.90)\end{array}$ & $\begin{array}{r}0.32 \\
(1.16)\end{array}$ \\
\hline$\Delta X L I$ Index & $\begin{array}{r}0.61 \\
(2.84)\end{array}$ & $\begin{array}{r}0.53 \\
(2.69)\end{array}$ & $\begin{array}{r}0.58 \\
(2.79)\end{array}$ & $\begin{array}{r}0.08 \\
(0.57)\end{array}$ & $\begin{array}{r}0.03 \\
(0.33)\end{array}$ \\
\hline Bernanke-Mihov shock & $\begin{array}{r}0.63 \\
(2.23)\end{array}$ & $\begin{array}{r}0.70 \\
(2.70)\end{array}$ & $\begin{array}{r}0.74 \\
(2.72)\end{array}$ & $\begin{array}{r}-0.07 \\
(0.36)\end{array}$ & $\begin{array}{r}-0.11 \\
(0.95)\end{array}$ \\
\hline$\Delta \ln ($ Real M2) & $\begin{array}{r}1.60 \\
(3.20)\end{array}$ & $\begin{array}{r}1.65 \\
(3.64)\end{array}$ & $\begin{array}{r}1.51 \\
(3.13)\end{array}$ & $\begin{array}{r}-0.06 \\
(0.17)\end{array}$ & $\begin{array}{r}0.08 \\
(0.40)\end{array}$ \\
\hline$\Delta$ Fed Funds Rate & $\begin{array}{c}-0.75 \\
(2.18)\end{array}$ & $\begin{array}{r}-1.12 \\
(3.60)\end{array}$ & $\begin{array}{r}-0.96 \\
(2.90)\end{array}$ & $\begin{array}{r}0.37 \\
(1.65)\end{array}$ & $\begin{array}{r}0.21 \\
(1.51)\end{array}$ \\
\hline$\Delta$ Discount Rate & $\begin{array}{r}-2.82 \\
(3.04)\end{array}$ & $\begin{array}{r}-3.61 \\
(4.31)\end{array}$ & $\begin{array}{r}-3.15 \\
(3.52)\end{array}$ & $\begin{array}{r}0.79 \\
(1.30)\end{array}$ & $\begin{array}{r}0.33 \\
(0.87)\end{array}$ \\
\hline$\Delta C P$ Spread & $\begin{array}{r}-3.57 \\
(3.70)\end{array}$ & $\begin{array}{r}-2.78 \\
(3.14)\end{array}$ & $\begin{array}{r}-3.15 \\
(3.36)\end{array}$ & $\begin{array}{r}-0.78 \\
(1.24)\end{array}$ & $\begin{array}{r}-0.42 \\
(1.04) \\
\end{array}$ \\
\hline
\end{tabular}


Table A

Variables

\begin{tabular}{|c|c|c|}
\hline Variable Names & Description/Comments & Source \\
\hline $\begin{array}{l}\text { NCF, KZ, IC, } \\
\text { D/E, FC, FCM }\end{array}$ & $\begin{array}{l}\text { Returns on zero cost portfolios buying firms with high } \\
\text { financial constraint measure, and shorting firms with low } \\
\text { financial constraint measure. }\end{array}$ & $\begin{array}{l}\text { Constructed by } \\
\text { authors using CRSP } \\
\text { and COMPUSTAT } \\
\text { data }\end{array}$ \\
\hline $\begin{array}{l}\text { RM-RF, HML, } \\
\text { SMB }\end{array}$ & $\begin{array}{l}\text { Market, book-to-market, and size factor-mimicking } \\
\text { portfolio returns }\end{array}$ & $\begin{array}{l}\text { Updated by Eugene } \\
\text { Fama from Fama and } \\
\text { French (1993) }\end{array}$ \\
\hline MOMENTUM & $\begin{array}{l}\text { Price momentum: a portfolio return constructed by } \\
\text { subtracting the returns from a portfolio experiencing low } \\
\text { eleven-month returns from the returns of a portfolio } \\
\text { experiencing high eleven-month returns. }\end{array}$ & Carhart (1997) \\
\hline DEFAULT & $\begin{array}{l}\text { The difference between total returns on Long-Term } \\
\text { Corporate Bonds and Long-Term Government Bonds. }\end{array}$ & CRSP \\
\hline TERM & $\begin{array}{l}\text { The difference between total returns on Long-Term } \\
\text { Government Bonds and U.S. } 30 \text { Day Treasury Bills. }\end{array}$ & CRSP \\
\hline IPO & $\begin{array}{l}\text { IPO: Excess returns on an equally-weighted portfolio } \\
\text { consisting of firms who in the last five years have had an } \\
\text { IPO. 77:1-94:12 }\end{array}$ & $\begin{array}{l}\text { Brav and Gompers } \\
\text { (1997) }\end{array}$ \\
\hline $\begin{array}{l}\text { DIVIDEND } \\
\text { OMISSIONS }\end{array}$ & $\begin{array}{l}\text { Excess returns on an equally-weighted portfolio consisting } \\
\text { of firms who in the last three years have omitted a } \\
\text { dividend. There are } 885 \text { total firms over the sample } \\
\text { period.68:7-90:11 }\end{array}$ & $\begin{array}{l}\text { Constructed by } \\
\text { authors using data } \\
\text { provided by } \\
\text { Michaely, Thaler, } \\
\text { and Womack (1995) }\end{array}$ \\
\hline $\begin{array}{l}\text { Real M2 } \\
\text { Fed Funds rate } \\
\text { Discount rate }\end{array}$ & Citibase codes: FM2DQ, FYFF, FYGD & Citibase \\
\hline $\begin{array}{l}\text { Bernanke- } \\
\text { Mihov Shock }\end{array}$ & $\begin{array}{l}\text { Innovations to the Federal Reserve reaction function, } \\
\text { estimated using a vector autoregression and scaled to be in } \\
\text { consistent units across different monetary regimes.68:7- } \\
94: 12\end{array}$ & $\begin{array}{l}\text { Bernanke and Mihov } \\
\text { (1995) }\end{array}$ \\
\hline CP Spread & $\begin{array}{l}\text { The difference between the commercial paper yield and the } \\
\text { 6-month T-bill yield (Citibase: FYCP-FYGM6) }\end{array}$ & Citibase \\
\hline LEI Index & $\begin{array}{l}\text { Index of Leading Economic Indicators, excluding stock } \\
\text { return component }\end{array}$ & Conference Board \\
\hline XLI Index & Experimental Leading Index & $\begin{array}{l}\text { Updated by James } \\
\text { Stock from Stock and } \\
\text { Watson (1989) }\end{array}$ \\
\hline
\end{tabular}




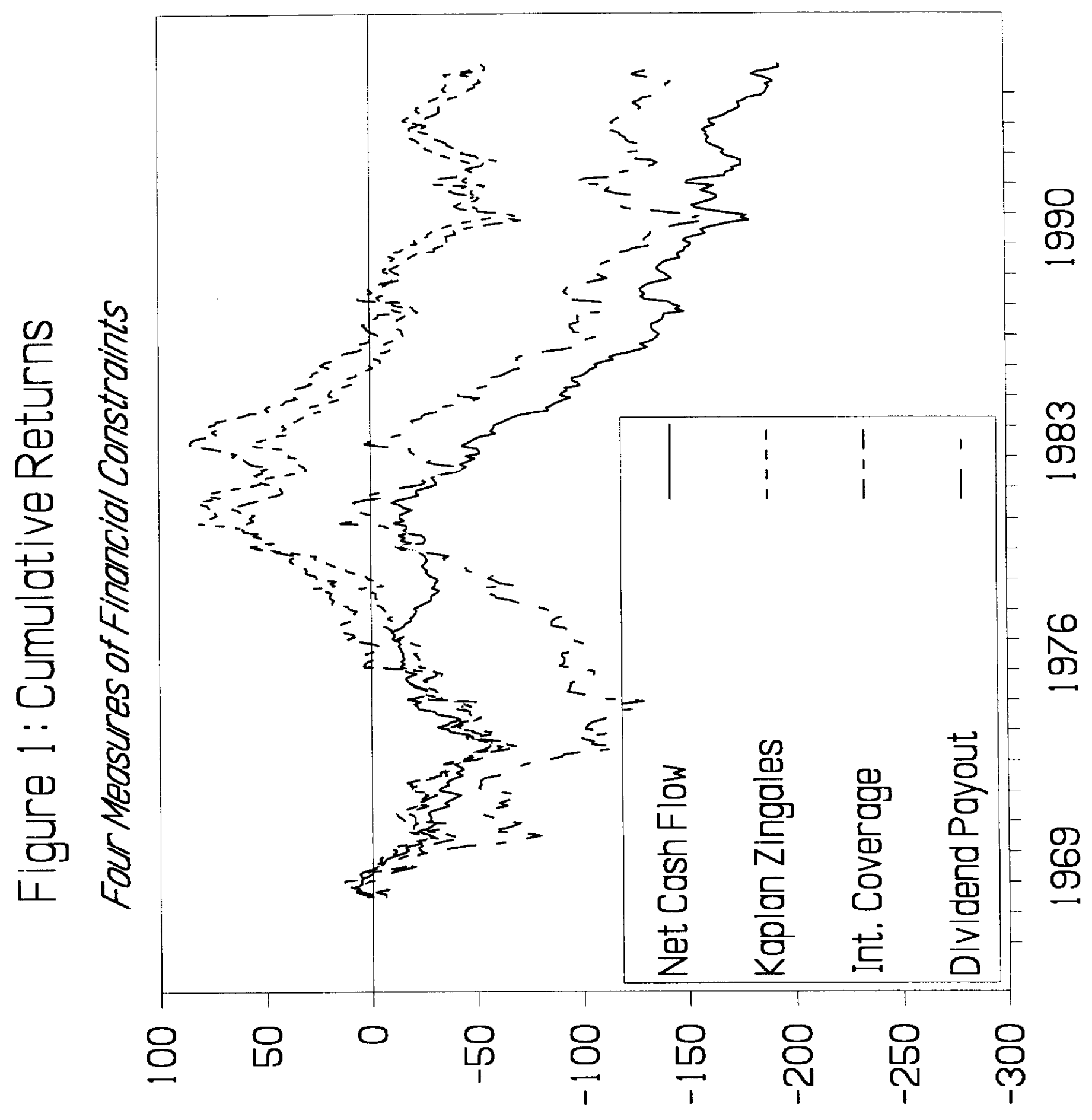

qบอวงอd 


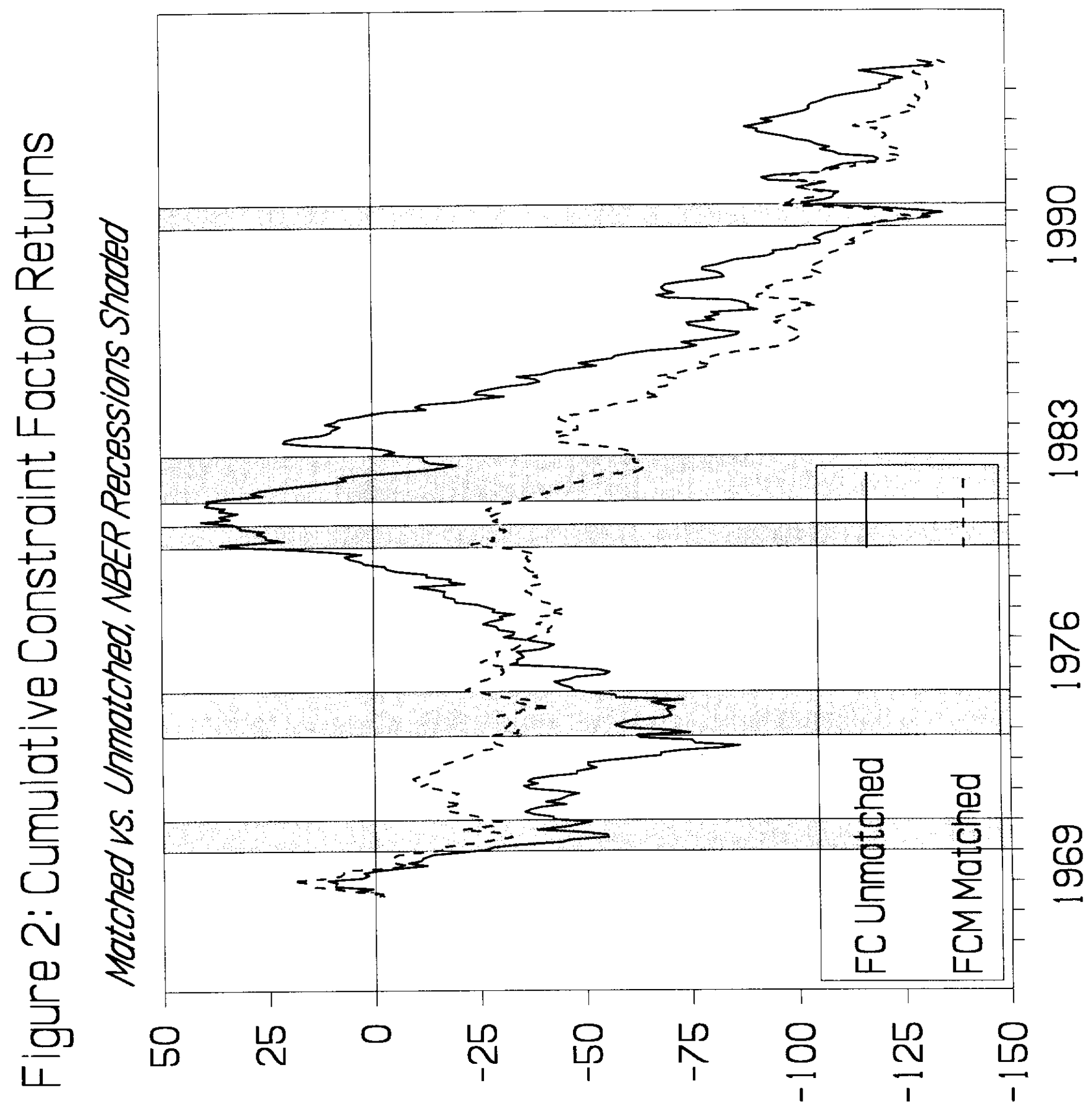

quอวงอd 